\title{
The Use of Moodle in Enhancing Students' Motivation
}

\author{
Sri Rosmiana ${ }^{1}$,Ita Sarmita Samad ${ }^{2}$, Mustakim ${ }^{3}$ \\ ${ }^{1}$ (English Department, Universitas Muhammadiyah Enrekang, Indonesia) \\ ${ }^{2}$ (English Department, Universitas Muhammadiyah Enrekang, Indonesia) \\ ${ }^{3}$ (English Department, Universitas Muhammadiyah Enrekang, Indonesia)
}

* Corresponding Author. E-mail: ${ }^{1}$ itaneverendita@gmail.com

\begin{abstract}
English-Indonesia)
Learning Management System (LMS) is currently being gradually integrated into the learning system especially in university level. Some studies have confirmed the good effects of applying the LMS toward the students' motivation, learning outcome, and the teaching and learning quality. Unfortunately, most of the teaching model used in STKIP Muhammadiyah Enrekang is still in conventional form. Thus, the researcher intends to conduct the research on the use of moodle as one of LMS online platform as a mean of updating the teaching model used in this institution. Consequently, the present study investigated a research question. That is the extent to which the use of moodle affects the students' motivation. The instruments used to collect the data is interview. The data collection was analyzed throughdescriptive analysis. The participants are all the second semester students of English education program in STKIPMuhammadiyah Enrekang in academic year 2019/2020. The result shows that the use of moodle can affect the students' motivation. There are at least 3 reasons can be concluded for this fact.The first reason is the communication features on moodle help students to communicate easily with peers or teachers.The second reason is moodle can be access anywhere and anytime. The third reason is the economical factor.
\end{abstract}

Keywords: Moodle; Blended Learning; Motivation

\section{Introduction}

Currently, Learning Management System (LMS) is progressively integrating into the learning system. The knowledge is transferred innovatively through web-based technology. It facilitates the teaching and learning process to run without getting to have face-to-face interaction.

Some studies have shown the positive effects of employing LMS. It improves the students' motivation (Bataineh, Banikalef, \& Albashtawi, 2019). English electronic instructional and methodological complex generates the best possible circumstances for the interactivity principle (Butova, Dubskikh, Kisel, \& Chigintseva, 2019). LMS can reinforce the students'

abilities and knowledge (Blas \& Fernandez, 2009). Blended learning application with assistance

of social networking was familiar to the students' daily life and reflected the present trend

towards learning and teaching development (Pospisilova, Bezdickova, \& Ciberova, 2011). In

other words, the application of LMS gives good impacts to the students' motivation, learning outcome, and the teaching-learning development.

Unfortunately, most of the teaching model used in STKIP Muhammadiyah Enrekang is still in the form of teacher-centered. The learning and teaching process is commonly 
conducted

conventionally. The media used is usually whiteboard or LCD to convey the knowledge to the

students. The technology-based media such as Email or google classroom is generally utilized only as assignment submission media.

Obviously, it is important to enhance the quality of the education system as a mean of improving students' learning performance. One of the efforts is by updating the teaching and learning model to be in accordance with the technology development. Either lecturer or teacher

has to be aware of this fact. Therefore, the implementation of such the LMS is necessary nowadays.

Several LMS platforms commonly used these days are schoology, edmodo, moodle, canvas, etc. Survey by Capterra (ferriman, 2016) and Elearning Industry (Pappas, 2014) put

moodle as the first rank of the top 20 most popular LMS software. Besides, studies have demonstrated the benefits of moodle. It enhances the students' autonomous learning ability

and save the teacher's energy ( $\mathrm{Zhu}, 2016)$. It improves the intrinsic and extrinsic of the students'

motivation as it correlated with the five elements of moodle recognition for EAP (Amer \&

Daher 2019).

The present study aims at investigating whether the use of moodle improves the students' motivation. It is urgent to conduct this research as the result is expected to provide useful feedbackfor the English teachers, students, and future researcher. It is hoped that it can improve theteachers' understanding of the moodle application. It can motivate the learners to learn Englishand thus enhance their success in learning. It can be a precious reference to support the future researcher in studying on the same topic of this research

\section{Method}

The participants of this research were all the second semester students of English education program of STKIP
Muhammadiyah Enrekang in academic year 2019/2020. They are chosen through purposive sampling technique. They were still in the beginner class and needed to maintain their learning motivation.

The research appliedqualitative research method. The data was collected through interview. The data was analyzed through the following technique based on Gay, Mills, and Airasian (2006).

a. Reading/ Memoing. In order to obtain the original feeling of the information, the

researcher reads and writes memos for all gathered observation and interview data.

Furthermore, it is crucial to the researcher to write marginal notes or brave issues or sections that seemed valuable and exceptionally closed to the objectives of this research.

b. Describing. The researcher starts to describe the respondents, the environment, and the phenomenon carefully and comprehensively over the research's rich complexity. It is an effort to prepare the narrative image of the environment and activities taking

place in it, thereby providing the researcher a sense of the context in which the study takes place.

c. Classifying. The researcher identifies and or classifies information components into groups.

\section{Result and Discussion}

The data collected through semi-structured interview is used to analyze whether the use of Moodle affect the students' motivation or not. The result confirmed that it works. The students become motivated to learn more about grammar when using moodle as 
the learning media. At least, there are some reasons can be concluded for this fact.

The first reason is the communication features on moodle help students to communicate easily with peers or teachers. They have a lot of chances to get in touch and discuss about the learning material. This is as suggested by student S5 and S7 who expressed "Yes, I like using moodle because I can ask my friends or my teacher easily through chat when there is something that I don't understand about". This is suitable with Ryan and Decy (2000) who explained that students have enough opportunities to interact with peers and teachers and thus motivated them to use the app again.

The second reason is moodle can be access anywhere and anytime. It is a mobile application. Thus, the students can review the material whenever they need it and wherever they are. This easiness enhances their motivation to engage in learning. It is expressecd by student S3 "I can study the lesson on my mobile phone and it makes simple for me to learn everywhere". It is in line with Waheed (2013) stated that the "anywhere" and "anytime" facilities of moodle help improve the students' motivation to access the learning.

The third reason is the economical factor. The students described that they do not need to spend their time and money to print the task given. They can simply uploaded their task on moodle and get the teacher's feedback as well. Besides, their task are savely archieved on this app. This fact also give high contribution to the students' motivation enhancement.

\section{Conclusion}

In conclusion, the use of moodle as a blended learning teaching media can affect the students' motivation to engage in learning. Both of the features and the learning material uploaded by the teacher/ lecturer on moodle supported the fact of this result. Then, it is suggested to apply such this learning media in English Class.

\section{References}

1. Amer, A. \& Daher, W. (2019). Moodle quizzes as a teaching tool in English for academic

purpose course. Int. J. Innovation and Learning, 25(1), 35-49. Retrieved from https://www.researchgate.net/publicatio n/330061094_Moodle_quizzes_as_a_te aching_tool_in_English_for_academic_ purposes_course

2. Barron, B. (2016). Apa itu moodle. Retrieved from https://business.tutsplus.com/id/articles/ what-is-moodle--cms-25815

3. Bataineh, K. B., Banikalef, A. A., \& Albashtawi, A. H. (2019). The effect of blended

learning on EFL students' grammar performance and attitudes: An investigation on moodle. Arab World English Journal, 11(1), 324-334.

Doi: https://dx.doi.org/10.24093/awej/vol10n o1.27.

4. Blas, T. M. \& Fernandez, A. S. (2009). The role of new technologies in the learning process: Moodle as teaching tool in physics. Computers and Education, 52 (2009), 35-44.

Doi: 10.1016/j.compedu.2008.06.005

5. Butova, A. V., Dubskikh, A.I., Kisel, O.V., \& Chigintseva, E. G. (2019). Electronic educational environment moodle in English language training. Arab World English Journal, 10(1), 47-55. Doi: https://dx.doi.org/10.24093/awej/vol10n o1.4

6. Ferriman, J. (2016). 20 Most popular learning management systems available today.

Retrieved 
Jurnal Edumaspul, 4 (2), Year 2020- 158

((Sri Rosmiana,Ita Sarmita Samad, Mustakim)

https://www.learndash.com/20-mostpopular-learning-managementsystemsinfographic/

7. Gay, L. R., Mills, G. E., \& Airasian, P. (2006). Educational research: Competencies for analysis and appications (8th ed.). Upper Saddle River, New Jersey: Pearson Education, Inc

8. Moodle. (2018). Retrieved from https://docs.moodle.org/37/en/Moodle app_features

9. Pappas, C. (2014). The 20 best learning management systems. Retrieved from https://elearningindustry.com/the-20best-learning-management-systems

10. Pospisilova, L., Bezdickova, Z., \& Ciberova, D. (2011). English for science using LMS moodle. 14th International Conference on Interactive Collaborative Learning (pp. 169-171).

Piestany, Slovakia: International
Conference Virtual University. Doi: 10.1109/ICL.2011.6059569

11. Sun, L. (2014). Investigating the effectiveness of moodle-based blended learning in college English course. Int. J. Information Technology and Management, 13(1), 83-94.

12. Thamrin, N. S., Suriaman, A., \& Maghfirah. (2019). Students' perception on the implementation of moodle web-based in learning grammar. IJOTL, 4(1), 1-10. Doi:

10.30957/ijotl-tl.v4iI.552.

13. Zhu, B. (2016). Construction of moodle information platform database and its application in interactive teaching of grammar. International Conference on Intelligent Transportation, Big Data \& Smart City (pp. 406-409). Doi: 10.1109/ICITBS.2016.116 